\title{
LAYANAN BIMBINGAN KELOMPOK UNTUK PENCEGAHAN PAHAM RADIKALISME DI PERGURUAN TINGGI ISLAM
}

\author{
Intan Sari \\ Intitut Agama Islam Negeri (LAIN) Bukittinggi \\ rezkintan87@,gmail.com
}

Diterima: 30 Juli 2019

Direvisi: 30 November 2019

Diterbitkan: 30 Desember 2019

\begin{abstract}
During the transition of the identity crisis, young people are likely to experience cognitive opening that makes them vulnerable to new, more radical ideas. Seeing this condition, Islamic Higher Education has an important role in preventing radicalism in students at Islamic Higher Education. Students need assistance and understanding so that they do not easily fall prey to radical movements, including through group counseling activities. In group guidance activities, group activities and dynamics must be realized to discuss various things that are useful for the development and problem solving of individuals (students) who become service participants. Group guidance activity aims to add insight into the knowledge skills, values, and attitudes of group members regarding the prevention of radicalism. This paper used a study of literature method, it is collecting various reading materials and information related to the phenomena and studies discussed. Based on the studies that have been carried out, it can be concluded that through the dynamics of groups that are actively predicted, it can increase the activity and participation of group members (students) in analyring and understanding Islamic ideas that are rahmatan lilalamin, tolerance, not fanatical towards certain groups, and strengthening nationalism.
\end{abstract}

Keywords: radicalism, group guidance, Islamic college.

\begin{abstract}
Abstrak
Pada masa transisi krisis identitas, generasi muda berkemungkinan untuk mengalami cognitife opening (pembukaan kognitif) yang membuat mereka rentan terhadap gagasan baru yang lebih radikal. Melihat pada kondisi tersebut, maka Perguruan Tinggi Islam memiliki peranan yang penting dalam upaya pencegahan paham radikalisme pada mahasiswa di Perguruan Tinggi Islam. Mahasiswa membutuhkan pendampingan dan pemahaman agar tidak mudah terjerumus pada gerakan radikal, antara lain melalui kegiatan bimbingan kelompok. Dalam kegiatan bimbingan kelompok, aktivitas dan dinamika kelompok harus diwujudkan untuk membahas berbagai hal yang berguna bagi pengembangan dan pemecahan masalah. Kegiatan bimbingan kelompok ini bertujuan menambah wawasan keterampilan pengetahuan, nilai dan sikap anggota kelompok mengenai pencegahan radikalisme. Metode yang digunakan dalam studi ini adalah kajian kepustakaan dengan mengumpulkan berbagai bahan bacaan dan informasi terkait fenomena dan kajian yang dibahas. Berdasarkan kajian yang telah dilakukan dapat disimpulkan bahwa melalui dinamika kelompok yang aktif dipredikasi dapat meningkatkan keaktifan dan keikut sertaan anggota kelompok (mahasiswa) dalam menganalisis dan memahami gagasan Islam yang rahmatan lilalamin, toleransi, tidak fanatik terhadap kelompok tertentu, dan memperkuat wawasan kebangsaan.
\end{abstract}

Kata Kunci: radikalisme, bimbingan kelompok, perguruan tinggi Islam. 


\section{Pendahuluan}

Indonesia adalah negara yang begitu kaya dengan adat, nilai dan budaya. Negara Indonesia adalah salah satu negara multikultur terbesar di dunia, hal ini dapat terlihat dari kondisi sosiokultural maupun geografis Indonesia yang begitu kompleks, beragam, dan luas. ${ }^{1}$ Indonesia terdiri atas sejumlah besar kelompok etnis, budaya, agama, dan lain-lain yang masing-masing plural (jamak) dan sekaligus juga heterogen (aneka ragam). Sebagai negara yang plural dan heterogen, Indonesia memiliki potensi kekayaan multi etnis, multikultur, dan multi agama yang kesemuanya merupakan potensi untuk membangun negara multikultur yang besar "multikultural nationstate". Dapat dikatakan, Indonesia merupakan negara multikultural yang memiliki kekayaan dari kemajemukan masyarakatnya.

Kemajemukan masyarakat sebagaimana yang ada di Indonesia adalah suatu keniscayaan yang tidak mungkin disangkal. ${ }^{2}$ Tidak ada cara lain bagi bangsa ini kecuali dengan berkomitmen kuat merawat keragaman menjadi sebuah kemungkin dan tidak mentolelir segala bentuk tindakan yang dapat menghancurkan tatanan masyarakat majemuk. Kemungkinan munculnya benih-benih percekcokan pada masyarakat multikultur sangat rawan terjadi jika masyarakat multikultur menyikapi perbedaan sebagai suatu pemisah dan menimbulkan sifat ke-kita-an (yang lain bukan bagian dari kita).

Masyarakat yang hidup ribuan tahun dalam keadaan yang multikultur tidak berarti telah immune terhadap kemungkinan-kemungkinan gesekan konflik etnis, budaya, agama, sosial, politik dan ekonomi. Pengalaman lama hidup dalam perbedaan ternyata tidak cukup untuk menanamkan rasa bangga akan perbedaan dan

${ }^{1}$ B. Kusumohamidjojo, Kebhinekaan Masyarakat Indonesia: Suatu Problematik Filsafat Kebudayaan (Jakarta: Grasindo, 2000), 15.

${ }^{2}$ Amirsyah, Meluruskan Salab Paham terbadap Deradikalisasi: Pemikiran, Konsep dan Strategi Pelaksanaan (Jakarta: Grafindo Khasanah Ilmu, 2012), 40.

${ }^{3}$ A. Faiz Yunus, "Radikalisme, Liberalisme, dan Terorisme: Pengaruhnya terhadap Agama Isalam", Jurnal memandangnya sebagai suatu kekayaan bangsa. Gesekan konflik tersebut akan sulit dihindari, jikamasyarakat multikultural tidak memiliki immune dari paham radikal atau radikalisme.

Radikalisme merupakan paham atau aliran yang menginginkan perubahan atau pembaharuan sosial dan politik dengan cara kekerasan atau drastic. $^{3}$ Dapat digambarkan bahwa radikalisme adalah suatu sikap yang mendambakan perubahan secara total dan bersifat revolusioner dengan menjungkirbalikkan nila-nilai yang ada secara drastis lewat kekerasan (violence) dan aksi-aksi yang ekstrem. Ada beberapa ciri yang bisa dikenali dari sikap dan paham radikal. 1) Intoleran (tidak mau menghargai pendapat \& keyakinan orang lain), 2) Fanatik (Selalu merasa benar sendiri; menganggaporang lain salah), 3) ekslusif (membedakan diri dari umat islam umumnya) dan 4) revolusioner (cenderung menggunakan caracara kekerasan untuk mencapai tujuan). ${ }^{4}$ Ciri-ciri paham radikalisme tersebut tidak dapat dibiarkan berkembang dan tumbuh pada indentitas pemuda Indonesia. Seharusnya pemuda Indonesia adalah hendaknya memiliki identitas yang menerima keragaman agar tidak rentan dengan potensi konflik.

Menurut data hasil penelitian indeks kerentanan radikalisme di Indonesia pada tahun 2011 yang di ungkap oleh Ketua Lembaga Swadaya Masyarakat Lazuardi Birru adalah 43,6 indeks radikalisme ini diperoleh dari hasil penelitian kerentanan radikalisme terhadap 33 propinsi dengan jumlah responden sebanyak $4840 .{ }^{5}$ Potensi konflik antar elemam masyarakat di Indonesia masih akan cukup tinggi pada lima hingga 10 tahun mendatang. Selain karena kondisi ekonomi yang belum sepenuhnya sejahtera, situasi ini juga terjadi

Studi Al Qur'an; Membangun Tradisi Berfikir Qur'ani, Vol.13, doi.org/10.21009/JSQ.013.1.06.

${ }^{4}$ A. M. Hendroprioyono, Terorisme: Fundamentalis Kristen, Yabudi dan Islam (Jakarta: Buku Kompas, 2009), 31.

${ }^{5}$ Kompas, Jumat 3 Febuari 2012 . Berita online https://www.kompas.com/nasional/2012/02/03/2256407 14/Tahun 2012 diakses 15 Desember 2019 
karena demokrasi di negeri ini masih belum matang. ${ }^{6}$

Radikalisme yang penulis maksud dalam kajian ini adalah individu atau kelompok yang tidak mengharagai perbedaan serta memaksakan pandangan kepada orang lain dengan cara kekerasan. Hal ini dapat memicu perpecahan antar umat beragama. Salah satu bentuk pencegahannya adalah dengan mengendalikan pemahan generasi muda akan pemahaman radikalisme itu sendiri.

Munculnya pemahaman seperti yang diungkapkan di atas membuat resah para akademis terutama di Perguruan Tinggai, karena dipahami bahwa mahasiswa berada pada masa akhir transisi baik secara kognitif maupun secara emosional. Perbedaan yang muncul dimasyarakat dianggap sebagai sebuah ancaman terhadap eksistensi mahasiswa. Jika perbedaan dianggap sebuah ancaman maka fanatisme akan berkembang di Indonesia. Kelompok fanatis akan menganggap kelompoknya yang paling benar, paling baik, sehingga akan merendahkan kelompok yang berbeda dengan kelompoknya.

Masa Transisi krisi identitas kalangan pemuda berkemungkinan untuk mengalami cognitive opening (pembukaan kognitif), sebuah proses mikro-sosiologis yang mendekatkan mereka pada penerimaan terhadap gagasan baru yang lebih radikal. Alasan-alasan seperti itulah yan menyebabkan mereka sangat rentan terhadap pengaruh dan ajakan kelompok tertentu lewat kekerasan. Melihat pada kondisi tersebut, maka perguruan tinggi memiliki peranan yang penting untuk mencetak sumber daya manusia yang anti radikalisme yaitu mahasiswa yang penuh toleransi dalam menerima perbedaan dan mampu bersinergi dalam membangun masa depan bangsa.

Perguruan Tinggi Islam dapat mewadahi penanaman wawasan keterampilan pengetahuan nilai dan sikap tersebut melalui profesi Bimbingan

${ }^{6}$ Zulfan Taufik, "Berebut Kuasa Rumah Tuhan: Ekspansi Ideologi Radikal Melalui Masjid di Kota Bekasi”, Islam Realitas: Journal of Islamic \& Social Studies, Vol. 4, No. 1 (2018): 21-38. dan Konseling. Profesi Bimbingan dan Konseling berfungsi memberikan pelayanan bantuan untuk peserta didik, siswa, mahasiswa baik secara perorangan maupun kelompok, agar mandiri dan berkembang secara optimal, dalam bimbingan pribadi, bimbingan sosial, bimbingan belajar dan bimbingan karir, melalui berbagai jenis layanan dan kegiatan pendukung berdasarkan norma-norma yang berlaku. Dalam tulisan ini yang dimaksud adalah salah satu layanan bimbingan dan konseling, yaitu layanan bimbingan kelompok.

Bimbingan kelompok merupakan bantuan terhadap individu yang dilaksanakan dalam situasi kelompok. ${ }^{7}$ Bimbingan kelompok dapat berupa penyampaian informasi ataupun aktivitas kelompok membahas masalah-masalah pendidikan, pekerjaan, pribadi dan sosial. Penulis mempersepsikan bahwa bimbingan kelompok dapat digunakahn sebagai wadah kegiatan untuk pencegahan paham radikalisme di Perguruan Tinggi. Hal tersebut di atas membuat penulis tertarik untuk mengkaji lebih dalam tentang "Layanan Bimbingan Kelompok Untuk Pencegahan Paham Radikalisme Di Perguruan Tinggi Islam"

\section{Pembahasan}

Pada bagian ini akan dibahas tentang topik-topik dalam tulisan ini, yaitu:

\section{a. Radikalisme}

Secara etimologis radikalisme berasal dari kata radix atau latin yang berarti akar yang kemudian menjadi inti dari makna radikalisme yang secara politik kemudian diarahkan setiap gerakan yang ingin merubah sistem dari akarnya. Rradikalisme adalah suatu komitmen kepada perubahan keseluruhan yakni yang menantang struktur dasar atau fundamental, tidak hanya pada lapisan-lapisan supervisial. ${ }^{8}$ Jadi paham radikalisme merupakan pemahaman yang menghendaki

\footnotetext{
${ }^{7}$ Ahmad Juntika dan Nurihsan, Manajemen Bimbingan dan Konseling di SMA (Jakarta: Grasindo, 2006), 26.

${ }^{8}$ F. K. Khalidjerni, Puspa RagamKonsep dan Isu Kewarganegaraan (Bandung: Widya Aksara Press, 2010), 45.
} 
perubahan keseluruhan secara secara drastis lewat kekerasan dan aksi-aksi yang ekstrem.

Pemerintah Indonesia membentuk Badan Nasional Penanggulangan Terorisme (BNPT) untuk mengatasi yang paham dan tindakan kekerasan/aksi-aksi yang mengganggu persatuan bangsa Indonesia. BNPT menggunakan dua strategi pertama, kontra radikalisasi yakni upaya penanaman nilai-nilai keIndonesiaan serta nilai-nilai non kekerasan, dalam prosesnya strategi ini dilakukan melalui pendidikan baik formal maupun non formal. Kontra radikalisasi diarahakan masyarakat umum melalui kerjasama dengan tokoh agama, tokoh pendidikan, tokoh masyarakat, tokoh adat, tokoh pemuda dan stakehorlder lain dalam memberikan nilai-nilai kebangsaan.

Strategi kedua adalah deradikalisasi, bidang deradikalisasi ditujukan pada kelompok simpatisan, pendukung, inti dan militan yang dilakukan baik dalam maupun di luar lapas. Tujuan dari deradikalisasi argar; kelompok inti, militan simpatisan dan pendukung meninggalkan cara-cara kekerasan dan teror dalam meperjuangkan misinya serta memoderasi paham-paham radikal mereka sejalan dengan semangat kelompok islam moderat cocok dengan misi-misi kebangsaan yang memperkuat NKRI

Melihat pada kondisi tersebut, maka Perguruan Tinggi Islam memiliki andil berperan penting untuk mencetak sumber daya manusia yang religius, berkarakter, dan cerdas yaitu mahasiswa yang religius, berkarakter, dan cerdas dalampemahaman multikultural, serta mampu memiliki sikap yang positif dalam menerima perbedaan, dan mampu saling menghargai dan bersinergi dalam membangun masa depan bangsa. Adapun peran lembaga pendidikan adalah mewadahi tempat bagi generasi muda atau mahasiswa untuk mencetak pemahaman yang anti radikalisme.

Berbagai upaya telah dilakukan oleh para pendidik maupun akademis terhadap penangkalan

${ }^{9}$ Januariang Munzaitu, Upaya Guru Pendidikan Agama Islam (PAI) dalam Menangkal Radikalisme pada Siswa Di radikalisme dikalangan pemuda. Salah satunya hasil penelitian Januariang tahun 2018 tentang upaya Guru Pendidikan Agama Islam (PAI) dalam Menangkal Radikalisme pada Siswa Di SMA Negeri 1 Boyolali Tahun Ajaran 2018/2019. Hasil penelitian menjelaskan adapun bentuk upaya yang dilakukan untuk menangkal radikalisme tersebut adalah sosialisasi sejak dini, pengintegrasian materi Pendidikan Agama Islam (PAI) dalam nilai-nilai antiradikalisme, dan mengedepankan dialog dalam pembelajaran. ${ }^{?}$

Berdasarkan hasil penelitian di atas disimpulkan bahwa perlunya suatu pemahaman dan wawasan yang tepat pada generasi muda untuk menangkal pemahaman radikal, serta dibutuhkan dialog yang tepat anata kaum terdidik dengan generasi muda untuk mencegah pemahaman yang keliru tentang radikalisme.

\section{b. Layanan Bimbingan kelompok}

Layanan bimbingan kelompok merupakan suatu cara memberikan bantuan (bimbingan) kepada individu (siswa) melalui kegiatan kelompok. Dalam layanan bimbingan kelompok, aktivitas dan dinamika kelompok harus diwujudkan untuk membahas berbagai hal yang berguna bagi pengembangan dan pemecahan masalah individu (siswa) yang menjadi peserta layanan.

Sejalan dengan itu Elida Prayitno (2007) megatakan bimbingan kelompok adalah satu jenis layanan dalam bimbingan konseling yang ditujukan kepada seseorang atau beberapa orang dengan memanfaatkan dinamika kelompok untuk memperoleh berbagai macam informasi dan pemahaman dari berbagai aspek, dari topik yang dibahas. Artinya layanan bimbingan kelompok merupakan salah satu layanan dari bimbingan dan konseling yang menggunakan dinamika dari kelompok dalam membahas berbagai informasi terhangat yang dibutuhkan anggota kelompok. Adapun tujuan layanan bimbingan kelompok

SMA Negeri 1 Boyolali Tabun Ajaran 2018/2019, (IAIN Surakarta: Sripsi, 2018), 2. 
adalah: a) Memberikan kesempatan -kesempatan pada siswa belajar hal-hal penting yang berguna bagi pengarahan dirinya yang berkaitan dengan masalah pendidikan, pekerjaan, pribadi dan sosial; b) Mempelajari masalah-masalah manusia pada umumnya; c) Menghilangkan keteganganketegangan emosi, menambah pengertian menangani dinamika kepribadian, dan mengarahkan kembali energi yang terpakai untuk memecahkan masalah-masalah tersebut dalam suasana yang permisif; d) Untuk mencapai tujuantujuan bimbingan secara lebih ekonomis dan efektif dari pada melalui kegiatan bimbingan individual. ${ }^{10}$

Prayitno juga menjelaskan tujuan lain dalam kegiatan bimbingan kelompok adalah:

a) Tujuan umum layanan bimbungan kelompok Secara umum, bimbingan kelompok bertujuan untuk membantu murid-murid yang mengalami masalah melalui prosedur kelompok, suasana kelompok yang berkembang dapat merupakan tempat bagi siswa untuk memanfaatkan semua informasi, tanggapan dan berbagai reaksi tematemannya untuk kepentingan pemecahan masalah. b) Tujuan khusus layanan bimbingan kelompok. Bertujuan melatih murid untuk berani mengemukakan pendapat dihadapan temantemannya, yang pada gilirananya dapat manfaatkan untuk ruang lingkup yang lebih besar seperti berbicara dihadapanorang banyak, dari forumforum resmi dan sebagainya. Melatih murid untuk dapat bersikap terbuka di dalam kelompok dan melatih murid untuk membina keakraban bersama teman-teman dalam kelompok khususnya, dan dengan teman-teman lainnya di luar kelompok pada umumnya. ${ }^{11}$

Berdasarkan paparan diatas dapat disimpulkan bahwa secara umum, tujuan dari bimbingan kelompok adalah sebagai berikut:

a) Mampu berbicara di depan orang banyak

\footnotetext{
${ }^{10}$ Sukardi dan Dewa Ketut, Bimbingan dan Penyuluhan Belajar di Sekolah, (Surabaya: Usaha Nasional, 1983), 51.

${ }^{11}$ Prayitno, Dasar-Dasar Bimbingan dan Konseling (Padang: UNP Pres, 2004), 196.

${ }^{12}$ Prayitno, Dasar-Dasar Bimbingan dan Konseling, 198.
}

b) Mampu mengeluarkan pendapat ide, saran, tanggapan, perasaan dan lain sebagainya kepada orang banyak

c) Belajar menghargai pendapat orang lain

d) Bertanggung jawab atas pendapat yang di kemukakaknnya

e) Mampu mengendalikan diri dan menahan emosi (gejolak kejiwaan) yang bersifat negatif.

f) Dapat bertenggang rasa

g) Menjadi akrab satu sama lainnya

h) Membahas masalah atau topik umum yang dirasakan atau menjadi kepentingan bersama.

Tujuan yang terdapat pada layanan bimbingan kelompok dimungkinkan dapat membantu generasi muda dalam mengembangkan pemahaman terkait radikalisme. Di dalam kegiatan layanan bimbingan kelompok juga terdapat asas yang berlaku. Asas ini bertujuan untuk membantu terlaksananya pelayanan secara optimal. Prayitno menjelaskan asas-asas dalam bimbingan kelompok yakni terkait a) kerahasiaan, b) kesukarelaan c) kegiatan d) keterbukaan e) kenormatifan, f) Keahlian. $^{12}$

Pemahaman radikalisme yang berkembang pada kaum muda sudah menjadi suau keharusan untuk segera diperbaiki. Sesuai dengan fungsi dari layanan Bimbingan kelompok yang dikemukan oleh Prayitno yakni berfungsi sebagai pemahaman, pencegahan, pengentasan, pengembangan dan pemeliharaan. ${ }^{13}$

Pelaksaan layanan bimbingan kelompok menjadi tepat dalam membantu generasi muda dalam memahami radikalisme yang berkembang. Pelaksanaan bimbingan kelompok menekankan pembahasan pada topik yang sedang hangat dibicarakan, hal ini sangat sesuai dengan konsep radikalisme yang sedang marak dibicarakan saat ini. Topik yang dapat dibahas dalam layanan bimbingan kelompok yakni berupa topik bebas dan topik tugas. ${ }^{14}$
13Prayitno, Dasar-Dasar Bimbingan dan Konseling , 198. ${ }^{14}$ Prayitno, Layanan Bimbingan dan Konseling Kelompok, 
Topik bebas yang dimaksud yakni topic yang berasal dari anggota kelompok yang dibahas dalam layanan bimbingan kelompok. Konselor sebagai pelaksana dalam kegiatan layanan ini dapat emngarahkan anggota kelompok untuk mengemukakan pendapat terkait fenomena atau fakta-fakta terkait radikalisme yang berkembang untuk dibahas secara positif.

Topik tugas yang diberikan oleh konselor dalam pelaksanaan layanan bimbingan kelompok merupakan topik yang disajikan oleh konselor sebagai pemimpin kelompok untuk membahas persoalan yang terjadi, salah satunya persoalan radikalisme. Dilaksanakannya layanan bimbingan kelompok secara tepat cara, tepat guna, dan tepat sasaran sesuai dengan tujuan, azas, fungsi dan topic yang dibahas diprediksi akan mampu membantu kaum terdidik dalam menangkal atau pemperbaiki pemahaman radikalisme yang berkembang saat ini.

Layanan bimbingan kelompok adalah sebuah pelayanan yang professional yang dikalsanakan dengan beberapa tahapan. Menurut Prayitno tahap-tahap bimbingan kelompok adalah sebagai berikut:

a) Tahap pembentukan

Tahap ini merupakan tahap pengenalan, tahap pelibatan diri atau pemasukan diri ke dalam kegiatan kelompok. Pola yang dilaksanakan secara keseluruhan pada tahap ini, termasuk tema, tujuan, kegiatan dan peranan pemimpin kelompok.

b) Tahap peralihan

Setelah susasana kelompok terbentuk dan dinamika kelompok sudah mulai tumbuh kegiatan berikutnya adalah peralihan antara tahap pertama dan tahap ketiga.

c) Tahap kegiatan

Tahap kegiatan merupakan inti kegiatan kelompok, maka aspek-aspek yang menjadi sisi dan pengiringnya cukup banyak, dan masingmasing aspek tersebut perlu mendapat perhatian yang seksama dari pemimpin kelompok. tahap ini merupakan kehidupan yang sebenarnya dari kelompok. Pada tahap kegiatan ini khususnya untuk pelayanan bimbingan kelompok di perguruan tinggi lebih tepatnya diarahkan dengan menggunakan topik tugas. Adapun contoh topik tugas yang bisa diberikan terkait pemahaman radikalisme adalah sebagai berikut:

1) Gagasan Islam yang rahmat lilalamin dan toleransi

2) Menjadi intelektual muda yang tidak fanatik terhadap kelompok tertentu

3) Intelektual muda yang memiliki wawasan kebangsaan Indonesia.

d) Tahap Penyimpulan

Tahap penyimpulan yaitu tahapan untuk melihat kembali apa yang sudah di lakukan dan dicapai oleh kelompok. Peserta kelompok diminta melakukan refleksi berkenaan dengan kegiatan pembahasan yang baru saja mereka ikuti.

e) Tahap pengakhiran

Setelah kegiatan kelompok memuncak pada tahap kegiatan, kegiatan kelompok ini kemudian menurun dan selanjutnya kelompok akan mengakhiri kegiatannya pada saat yang tepat. Pokok perhatian utama dalam tahap ini adalah bukan pada beberapa kali kelompok itu harus bertemu, tetapi pada hasil yang telah dicapai kelompok itu ketika menghentikan pertemuannya. Dalam pembahasan frekuensi pertemuan, hendaknya di bahas tentang kapan dan berapa kali pertemuan akan dilakukan. Sedangkan pada pembahasan keberhasilan kelompok, hendaknya terfokus pada komitmen anggota kelompok. ${ }^{15}$

Dari uraian di atas dapat disimpulkan kegiatan bimbingan kelompok terdiri dari lima tahap yaitu tahap pembentukan, peralihan, kegiatan, penyimpulan, pengakhiran. Tahapan ini merupakan rangkaian yang dapat digunakan dalam membatu generasi muda untuk memahami
${ }^{15}$ Prayitno, Jenis layanan dan Kegiatan PendukungKonseling (Padang: Fakultas Ilmu Pendidikan UNP, 2012), 30 . 
pemahaman dan kajian radikalisme yang berkembang, sehingga pemahaman dan kajian tersebut tidak menjadi cikal bakal sebuah prilaku radikal pada generasi muda/ mahasiswa.

\section{Kesimpulan}

Fenomena dan kajian yang diungkapkan di atas dapat disimpulkan bahwa, salah satu pelayaan yang terdapat pada Bimbingan dan Konseling yakni layanan bimbingan kelompok merupakan salah satu tawaran solusi yang dapat dikaji secara eksperimen nantinya dalam alternatif pencegahan pemahaman dan radikalisme mahasiswa di Perguruan Tinggi. Layanan ini digunakan dengan memanfaatkan dinamika kelompok.

Dinamika kelompok yang aktif dipredikasi dapat meningkatkan keaktifan dan keikut sertaan anggota kelompok (mahasiswa) dalam menganalisis dan memahami gagasan islam yang rahmatan lilalamin, toleransi, tidak fanatik terhadap kelompok tertentu, dan memperkuat wawasan kebangsaan. Analisis yang dikembangkan dalam kelompok adalah berdasarkan fenomenafenomena serta informasi yang sedang berkembangn saat ini. Dengan menggunakan dinamika kelompok dan kemampuan konselor yang mumpuni, maka kegiatan kelompok akan hidup dan terjalin keakraban sesama anggota kelompok. Proses kegiatan ini dilakukan pada tahap kegiatan.

Kegiatan layanan bimbingan kelompok dilaksanakan dalam lima tahap, yaitu: (1) tahap pembentukan (2) tahap peralihan (3) tahap kegiatan (4) tahap penyimpulan (5) tahap pengakhiran. Pembahasan topik yang mendalam dan tuntas diharapkan dapat mencegah paham radikalisme mahasiswa di Perguruan Tinggi Islam.

\section{Daftar Pustaka}

Amirsyah. Meluruskan Salab Pabam terbadap Deradikalisasi: Pemikiran, Konsep dan Strategi Pelaksanaan. Jakarta: Grafindo Khasanah Ilmu, 2012.
Hendroprioyono, A. M. Terorisme: Fundamentalis Kristen, Yahudi dan Islam. Jakarta: Buku Kompas, 2009.

Juntika, Ahmad dan Nurihsan. Manajemen Bimbingan dan Konseling di SMA. Jakarta: Grasindo, 2006.

Khalidjerni, F. K. Puspa RagamKonsep dan Isu Kewarganegaraan. Bandung: Widya Aksara Press, 2010.

Kompas, Jumat 3 Febuari 2012 . Berita online https://www.kompas.com/nasional/2012 /02/03/225640714/Tahun 2012 diakses 15 Desember 2019

Kusumohamidjojo, B. Kebhinekaan Masyarakat Indonesia: Suatu Problematik Filsafat Kebudayaan. Jakarta: Grasindo, 2000.

Munzaitu, Januariang. Upaya Guru Pendidikan Agama Islam (PAI) dalam Menangkal Radikalisme pada Siswa Di SMA Negeri 1 Boyolali Tabun Ajaran 2018/2019. (IAIN Surakarta: Sripsi, 2018.

Prayitno. Dasar-Dasar Bimbingan dan Konseling. Padang: UNP Pres, 2004.

Prayitno. Jenis layanan dan Kegiatan Pendukung Konseling. Padang: Fakultas Ilmu Pendidikan UNP, 2012.

Sukardi dan Dewa Ketut. Bimbingan dan Penyuluban Belajar di Sekolah. Surabaya: Usaha Nasional, 1983.

Taufik, Zulfan. "Berebut Kuasa Rumah Tuhan: Ekspansi Ideologi Radikal Melalui Masjid di Kota Bekasi", Islam Realitas: Journal of Islamic \& Social Studies, Vol. 4, No. 1 (2018): 21-38.

Yunus, A. Faiz. "Radikalisme, Liberalisme, dan Terorisme: Pengaruhnya terhadap Agama Isalam" Jurnal Studi Al Qur'an; Membangun Tradisi Berfikir Qur'ani, Vol. 13, doi.org/10.21009/JSQ.013.1.06. 